\title{
Author Correction: Dynamic cellular phenotyping defines specific mobilization mechanisms of human hematopoietic stem and progenitor cells induced by SDF1 $\alpha$ versus synthetic agents
}

Cornelia Monzel $\left.\right|^{1,4}$, Alexandra S. Becker ${ }^{1}$, Rainer Saffrich $\mathbb{1}^{2,5}$, Patrick Wuchter ${ }^{2,5}$, Volker Eckstein ${ }^{2}$, Anthony D. $\mathrm{Ho}^{2}$ \& Motomu Tanaka ${ }^{1,3}$

Correction to: Scientific Reports https://doi.org/10.1038/s41598-018-19557-x, published online 30 January 2018

The original version of this Article contained a typographical error in the title.

"Dynamic cellular phynotyping defines specific mobilization mechanisms of human hematopoietic stem and progenitor cells induced by SDF1 $\alpha$ versus synthetic agents"

now reads:

"Dynamic cellular phenotyping defines specific mobilization mechanisms of human hematopoietic stem and progenitor cells induced by SDF1 $\alpha$ versus synthetic agents"

This error has now been corrected in the PDF and HTML versions of the Article.

(c) Open Access This article is licensed under a Creative Commons Attribution 4.0 International cc. License, which permits use, sharing, adaptation, distribution and reproduction in any medium or format, as long as you give appropriate credit to the original author(s) and the source, provide a link to the Creative Commons license, and indicate if changes were made. The images or other third party material in this article are included in the article's Creative Commons license, unless indicated otherwise in a credit line to the material. If material is not included in the article's Creative Commons license and your intended use is not permitted by statutory regulation or exceeds the permitted use, you will need to obtain permission directly from the copyright holder. To view a copy of this license, visit http://creativecommons.org/licenses/by/4.0/.

(C) The Author(s) 2018

\footnotetext{
${ }^{1}$ Physical Chemistry of Biosystems, Institute of Physical Chemistry, Heidelberg University, 69120, Heidelberg, Germany. ${ }^{2}$ Department of Medicine V, Heidelberg University, 69120, Heidelberg, Germany. ${ }^{3}$ Institute for IntegratedCell-Material Sciences, Kyoto University, 606-8501, Kyoto, Japan. ${ }^{4}$ Present address: Laboratoire Physico-Chimie, Institut Curie, CNRS UMR168, 75005, Paris, France. ${ }^{5}$ Present address: Institute of Transfusion Medicine and Immunology, Medical Faculty Mannheim, Heidelberg University, German Red Cross Blood Service Baden-Württemberg - Hessen, 68167, Mannheim, Germany. Correspondence and requests for materials should be addressed to A.D.H. (email: anthony_dick.ho@urz.uni-heidelberg.de) or M.T. (email: tanaka@uni-heidelberg.de)
} 